\title{
Research-Oriented Learning and Teaching from a Didactic Perspective
}

\author{
Karin Reiber
}

The following article explains the didactic challenges of inquiry-based learning in light of the current, in part paradigmatic, shift in university education. To this end, I will outline the charged relationship between the traditional ideal of education and contemporary societal and educational policy expectations for academic studies, in which the teaching and learning at institutions of higher learning are currently situated. In order to counteract the oft-lamented conceptual blurring of inquiry-based learning, I have undertaken to limit and delineate the use of the term. The classification of the approach within the context of the history of ideas serves to make clear the complex historical social causal network within which university education must be interpreted and shaped. Furthermore, I undertake an internal differentiation of inquiry-based learning in order to be able to systematize various degrees of expression and forms. The next step is to develop research-oriented learning and teaching in an evolutionary way by structuring these progressively along a course of studies based on this development-oriented approach. Manifestations of inquiry-based learning are ordered and classified by differentiating between various dimensions of understanding and knowledge, and taking into account different course formats. Finally, not only the opportunities and scope of inquiry-based learning, but also limitations and risks are outlined in order to avoid an overly euphoric stylization of the approach, while ignoring specific structural and curricular deficits.

\footnotetext{
K. Reiber, Prof. Dr. $(\bowtie)$

Hochschule Esslingen, Professur für Erziehungswissenschaft/Didaktik,

Esslingen am Neckar, Germany

e-mail: Karin.Reiber@hs-esslingen.de
} 


\subsection{Research and Teaching Caught Between Innovation and Tradition}

The historical ideal of university education is based on an understanding of education, the mainstay of which is scholarship and research. Here three basic postulates are combined (cf. Euler 2005):

- research and teaching constitute an inseparable unit;

- teaching and learning are closely related to one another as a form of research communication;

- despite its differentiation into different disciplines, scholarship constitutes an entity unto itself.

This educational ideal goes back to the Humboldtian university reform and has become the normative concept for university education, even if it was never realized in its full manifestation (cf. Aepkers 2002).

Today, the historical concept of university education is in conflict with higher education teaching, which has been shaped by the Bologna Process and which is dedicated to the stated goal of "employability." Its external characteristics are, to name but a few of the most prominent ones, highly regulated degree programs with a precisely calculated workload, examinations that accompany the course of study rather than the previous central final examinations as well as an overall focus on the expected results in the form of competencies ("outcome orientation") in contrast to the conventional focus on the discipline's constitutive content ("input orientation"). The associated opportunities and risks are now well known due to widespread discussion, both amongst higher education policymakers and also publicly: On the one hand, the degree programs are becoming more predictable and calculable both for students and for the institutions of higher learning, and those programs are gaining legitimacy due to their transparent and labor market-related goals; on the other hand, students and educators are losing much of their freedom to determine their own focus, and the perceived workload has increased significantly for both (cf. Reiber 2012).

While the intention of the Bologna reform is to increase the number of academically qualified persons, global research competition also brings with it demands that research be conducted at a high level of excellence (cf. Reiber and Tremp 2007). This creates an additional charged relationship for institutions of higher learning: To put it succinctly, they are becoming mass institutions of education on the one hand, and with their research, they are involved in a national and international competition for money and reputation on the other (cf. Huber 2004).

The original concept behind a university education which entails the development of the entire person - meaning not just their cognitive abilities - so that they are able to act responsibly in a manner that is self-determined and ethical, but which also entails a professional qualification as a side effect (as it were) (cf. Webler 2008), can be adapted for the 
Bologna philosophy with its primacy of employability (cf. Horn 2007). Contemporary concepts of university education are likewise based on a comprehensive educational goal, which considers cognitive and personal skills development to be as important as the ethical power of judgment (for Leuphana University of Lüneburg cf. e.g. Spoun 2007).

The orientation of higher education instruction towards clearly definable results is closely related to the key objective of employability. However, this is by no means new, nor an invention of the Bologna reform: The postulate of outcome orientation has already been discussed in higher education didactics using the slogan of "the shift from teaching to learning" (cf. Wildt 2003). The teaching-related perspective, which focuses on the selection of content and options for imparting that content, should be transformed into a learning-related perspective: What is important are the learning outcomes, i.e. what is actually acquired by students, their knowledge, skills and their mindset.

In recent discourse pertaining to higher education didactics as well, this "learningoutcome perspective" is the standpoint from which teaching-learning processes can be analyzed and balanced. This opens up significantly more design leeway than an attitude towards teaching that believes students can be classified as either "good" or "bad" in order to henceforth focus on the good students ("blame-the-students perspective"). With respect to the equally one-sided attitude of educators who see learning success solely in terms of their own abilities as an educator ("blame-the-teacher perspective"), the outcome orientation has the advantage: Certainly "bad" educators can improve as a result of appropriate training and techniques; however, in so doing they become even more focused on themselves, and often from a perspective that has been narrowed down to methodical "tricks," than they are on the learning processes of the students (cf. Biggs and Tang 2011). A differentiated analysis of the teaching-learning process and an improvement of the teaching quality is only possible when the mutual influence of teaching and learning, and their respective strengths and development potential, are perceived.

\subsection{Conceptual Distinctions and Limitations}

To begin with, we define inquiry-based learning as a target for research-oriented teaching in such a way that both learning and teaching follow the problem-solving process of research and reproduce its individual work steps as learning phases, as it were. Ultimately, the aim of this teaching and learning is to give rise to recognizable added value in terms of knowledge with innovative content, which can, in turn, serve as the starting point and reference point for further research and learning processes. This teaching and learning is tied to the form of research communication, which serves to facilitate the integration of processes and results into the discipline (cf. Reiber and Tremp 2007).

If one now attempts to classify inquiry-based learning in terms of the history of ideas, the objectives and function of this approach become more apparent, and it becomes clear that this is more than just one didactic variety among many. While the topic of inquirybased learning initiated by the Federal University Assistants' Conference (BAK) in the 
1970s was widely discussed, this was followed by a phase in which the approach was addressed, in particular in works on teacher education (cf. for example Wildt 2005). Inquiry-based learning is dealt with here, in particular within the context of practical studies, with the objective of didactically making practical experience the starting point for the "initiation or founding of skills in scholarly reflection [...] [and] the development of a metacognitive capacity for reflection" (Weyland 2010, p. 246), while at the same time providing insight into the contingency of pedagogical action and its theoretical attempts at explanation and justification.

It is only in the course of the Bologna reform that a broad discussion concerning inquiry-based learning was again rekindled and that this old and self-evident principle of university education was rediscovered for many disciplines (cf. Huber 2009; Hofhues et al. 2014). For the first time, this implicit principle of inquiry-based learning became a consciously postulated guiding principle when it came to the democratization of university relations by developing the Humboldtian educational ideal. A return to the core of university education was a reflexive response to the Bologna reform: The transition to bachelor's and master's degree programs was and is tied to the fear that academic education processes might be reduced to vocational qualification. Within the context of contemporary history and the history of ideas, inquiry-based learning has become a central concept in efforts concerning the maintenance, renaissance, and also the contemporary development of the notion of a university education.

The focus in the recent discussion of inquiry-based learning has therefore been on maintaining a comprehensive educational goal within the context of higher educational studies that encompasses cognitive and personal development as well as the development of an ethical power of judgment, even under changed basic conditions. To this end, leeway in terms of content is possible and necessary in order to accommodate individual prioritization, even in degree programs having a regulated curriculum (cf. Spoun 2007).

A further and more detailed definition of the "inquiry-based teaching and learning" format can be made by distinguishing it from those educational processes that occur in other sub-segments of the education system. Ideally speaking, these are the following fundamental differentiating features:

- In contrast to the learning processes that take place in schools, in particular at the upper secondary level, a university education includes the cognitive process itself to a much greater degree (cf. Webler 2007). Knowledge is discussed more in connection with the formation of the insights, reflected upon, and therefore received more critically than is the case in schools.

- While knowledge and insight are brought into focus with greater emphasis on the (professional) functional perspectives during a vocational education, inquiry-based learning as a principle of academic study correlates this with a critical reflection on the application context (cf. Kossek 2009).

- In no other educational sector does research serve as intensely as the basic mode of teaching and learning than in higher education (cf. Tremp and Futter 2012). 


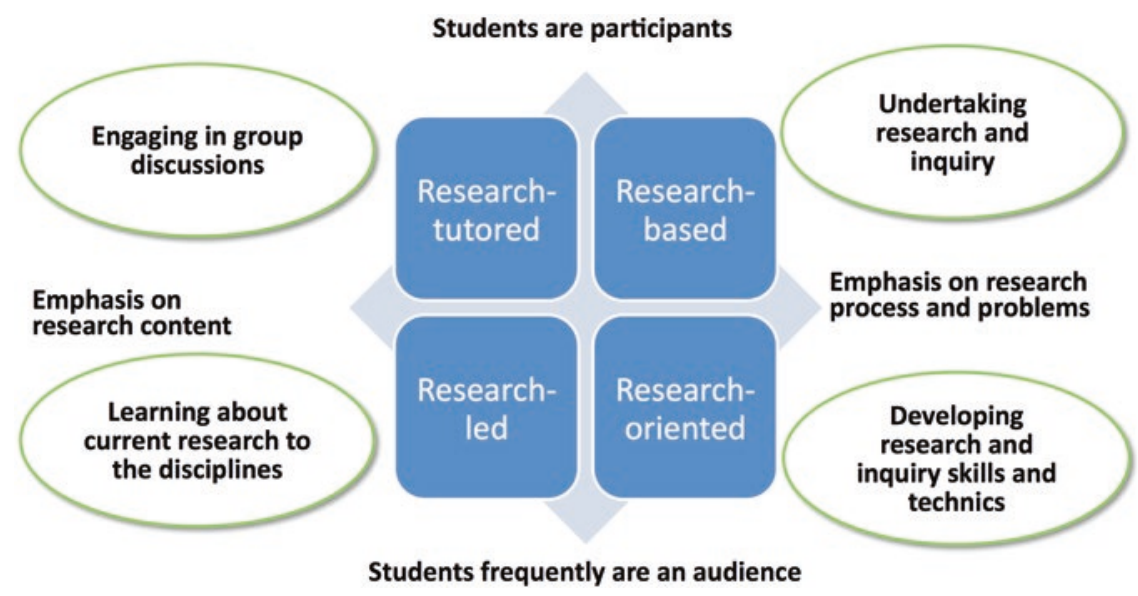

Fig. 4.1 Various degrees of expression of research-related learning; author's representation according to Jenkins and Healey (2011, p. 38)

It is possible to differentiate between various degrees of expression by tracing the two charged relationships in inquiry-based learning (see Fig. 4.1): It can be classified between the poles of participatory and receptive student roles, and can be defined along the continuum of a clearer focus on the research results and research content or research problem and process (cf. Jenkins and Healey 2011).

In the discourse on research-related teaching, the pure form of inquiry-based learning is now frequently, and usually implicitly, assumed; it entails the idea, already anchored in the curriculum, that students largely learn through their own research activities and has an increased emphasis on the process itself (right upper quadrant in the diagram: research-based).

From this perspective, learning is conceptualized in steps analogous to the phases of the research process (cf. e.g. Wildt 2009). However, one can object that there are also constitutive differences between the two basic operations of research and learning: In research, as a rule, self-organization and determination are generally greater than in learning processes (especially if these are associated with academic performance/test performance). The research process is characterized by even greater uncertainty and potentially also harbors the possibility of failure; learning processes imply stronger hierarchical relationships between the agents than is commonly the case in a research community (cf. Hofhues et al. 2014). Overall, there is a fundamental difference between the claim to scholarship and to education at institutions of higher learning (cf. Huber 2009).

From a developmental perspective, the next step is to conceptualize the research-related learning from the perspective of teaching. 


\subsection{Research-Related Learning from a Development-Oriented Perspective}

If, from a didactic perspective, one considers the entire course of study as a development process, inquiry-based learning ultimately involves the gradual acquisition of the necessary sub-competences, whereby all the sub-steps have both their own intrinsic logic and their intrinsic value, and the goal of which is the "systematic development of an approach that has a scholarly basis and that is committed to scholarly values" (Tremp and Hildbrand 2012, p. 109).

From this developmental perspective, the acquisition of research-related competency can be described using the taxonomy provided by Anderson and Krathwohl (2001). The horizontal axis of this matrix maps the various quality levels of learning processes as goal dimensions (see Fig. 4.2). The vertical axis differentiates between various knowledge dimensions. The horizontal goal dimensions are a progressive gradation which extends from "remember" to "create," and which thus represents different levels of learning. In terms of knowledge dimensions, Anderson and Krathwohl (2001) distinguish between factual knowledge, abstract conceptual knowledge, process-oriented procedural knowledge and metacognitive knowledge.

Competency development can be planned using this matrix for the various degrees of expression of research-related learning by combining differing yet mutually complementary teaching-learning formats (e.g. lecture, seminar or tutorial) and by combining cognitive dimensions of different scope with different types of knowledge within these courses. If one now places one phase model on top of the other (Jenkins and Healey 2011; Anderson and Krathwohl 2001), inquiry-based learning can be anchored as a study objective in the curricular sequence, and can be didactically operationalized and designed over modules and with different teaching and examination formats. Thus, for example, up-to-date research results could be imparted as fundamental knowledge within the context of a lecture. In addition to this, students would apply this factual knowledge by preparing their

\begin{tabular}{|c|c|c|c|c|c|c|}
\hline & Remember & Understand & Apply & Analyze & Evaluate & Create \\
\hline $\begin{array}{l}\text { Factual } \\
\text { Knowledge }\end{array}$ & & \multirow{2}{*}{$\begin{array}{l}\text { e.g. } \\
\text { Lecture: } \\
\text { research- } \\
\text { led }\end{array}$} & \multirow{2}{*}{$\begin{array}{l}\text { e.g. } \\
\text { Presenta- } \\
\text { tion: } \\
\text { research- } \\
\text { oriented }\end{array}$} & & & \\
\hline $\begin{array}{l}\text { Conceptual } \\
\text { Knowledge }\end{array}$ & & & & \multirow{2}{*}{\multicolumn{2}{|c|}{$\begin{array}{l}\text { e.g. } \\
\text { Case Study: } \\
\text { research- } \\
\text { tutored }\end{array}$}} & \multirow{3}{*}{$\begin{array}{l}\text { e.g. } \\
\text { Research } \\
\text { Project: } \\
\text { research- } \\
\text { based }\end{array}$} \\
\hline $\begin{array}{l}\text { Procedural } \\
\text { Knowledge }\end{array}$ & & & & & & \\
\hline $\begin{array}{l}\text { Metacognitive } \\
\text { Knowledge }\end{array}$ & & & & & & \\
\hline
\end{tabular}

Fig. 4.2 Research-related learning from a development-oriented perspective; on the basis of Anderson and Krathwohl (2001); source: author's representation 
own presentations while accompanying the research. Building on this, the dimension of process-oriented procedural knowledge is added and, within the context of case studies, the learning levels of analysis and evaluation are addressed within the context of researchoriented learning. Finally, research-based learning can occur in the form of projects within a tutorial, in which new knowledge or, respectively, new solutions for a clearly defined practical problem can be developed; at the latest, this learning method also implicates the knowledge dimension of metacognitive knowledge, since projects also always include reflection on one's own learning and working processes (see Fig. 4.2).

As such, the individual cognitive steps, knowledge dimensions and various degrees of expression relating to the extent of the students' participation, as well as the focus on the research process and result, have their time and place in the course of study - and their respective justifications. This is because, in the synopsis of all of the components and the way in which these complement one another, research-related learning can also be didactically grasped and developed more precisely.

\subsection{Consequences and Conclusions}

From this perspective of university education, which is as much developmentally oriented as enabling oriented, in the conflict of objectives between research and employability outlined above, it is possible to describe the overriding goal of university education as "professionalism through scholarship" (Brinckman et al. 2002, p. 29). As such, a research-based and responsible attitude is defined as a specific feature of university education, which refers to a dynamic concept of knowledge. As such, learning is a continuous, reflective process of cognition and the construction of knowledge; it can only be performed in a manner that is active, engaged and critical (cf. Kossek 2009). Within this understanding, professional employability means a general vocational orientation which adequately addresses the "growing complexity and uncertainty" (Kossek 2009, p. 5) of our society.

Pursuant to the Humboldtian concept of a university education, it is the task of university educators to generate new knowledge themselves, or to test new knowledge and to make this accessible to others. In the spirit of a contemporaneous, vocationally oriented university education, this claim can be turned around in terms of higher education didactics: University instructors can stage teaching-learning processes as small research projects of varying scope and make these transparent. In so doing, it is important to reflect on the process and developmental nature of a course of study with a view to acceptance on the part of the students. Since inquiry-based learning may always be accompanied by phases of uncertainty on the part of students, appropriate support offers must be provided to guide the teaching-learning process if needed; however, at least one exchange forum for this process must be offered. In any case, university instructors are role models for the approach of inquiry-based learning, independent of whether they teach in a specific field, in which they themselves conduct research, or in which they are at least active in a research capacity. 
Thus for all involved, inquiry-based learning is an ambitious form of education through scholarship (Bildung durch Wissenschaft). It requires didactic planning, design and evaluation. At the same time, like any other serious didactic approach, inquiry-based learning must not be misunderstood as a "smoothing and acceleration of learning pathways" (Rumpf 2007, p. 50), but rather as a deceleration caused by the fact that the "initial attentiveness" (ibid.) is reestablished as a starting point for subjectively meaningful learning.

\section{References}

Anderson, L. W./Krathwohl, D. R. (2001). A Taxonomy for Learning, Teaching and Assessing. A Revision of Bloom's Taxonomie of Educational Objectives. New York u. a.: Longman.

Aepkers, M. (2002). Forschendes Lernen - Einem Begriff auf der Spur. In M. Aepkers/S. Liebig (Hrsg.), Entdeckendes, forschendes und genetisches Lernen (S. 69-87). Baltmannsweiler: Schneider-Verlag Hohengehren.

Biggs, J./Tang, C. (2011). Teaching for Quality Learning at University. New York: Open University Press.

Brinckman, H./Garcia, O./Gruschka, A./Lenhardt, G./ZurLippe, R. (2002). Die Einheit von Forschung und Lehre: Über die Zukunft der Universität. Wetzlar: Büchse der Pandorra.

Euler, D. (2005). Forschendes Lernen. In W. Wunderlich/S. Spoun (Hrsg.), Studienziel Persönlichkeit. Beiträge zum Bildungsauftrag der Universität heute (S. 253-272). Frankfurt/New York: Campus-Verlag.

Hofhues, S./Reinmann, G./Schiefner-Rohs, M. (2014). Lernen und Medienhandeln im Format der Forschung. In O. Zawacki-Richter/D. Kergel/N. Kleinefeld/P. Muckel/J. Stöter/K. Brinkmann (Hrsg.), Teaching Trends 2014 (S. 19-36). Münster: Waxmann.

Horn, K.-P. (2007). Lehren und Lernen an Hochschulen - Historisches Erbe und Zukunftsauftrag. In K. Reiber/R. Richter (Hrsg.), Entwicklungslinien der Hochschuldidaktik - Ein Blick zurück nach vorn. Dokumentation der gleichnamigen Tagung vom 29.11. bis 1.12. 2006 in Tübingen (S. 27-41). Berlin: Logos.

Huber, L. (2004). Forschendes Lernen: 10 Thesen zum Verhältnis von Forschung und Lehre aus der Perspektive des Studiums. die hochschule, 13(2), 29-49.

Huber, L. (2009). Warum Forschendes Lernen nötig und möglich ist. In L. Huber/J. Hellmer/ F. Schneider (Hrsg.), Forschendes Lernen im Studium (S. 9-35). Bielefeld: Universitätsverlag Webler.

Jenkins, A./Healey, A. (2011). Research based learning - a collection of case studies in different disciplines. In I. Jahnke/J. Wildt (Hrsg.), Fachbezogene und fachübergreifende Hochschuldidaktik (S. 37-46). Bielefeld: W. Bertelsmann Verlag.

Kossek, B. (2009). Survey: Die forschungsgeleitete Lehre in der internationalen Diskussion. Retrieved 31 March 2015 from https://ctl.univie.ac.at/fileadmin/user_upload/elearning/ Forschungsgeleitete_Lehre_International_090414.pdf

Reiber, K. (2012). Forschendes Lernen im Zeichen von Bologna. In B. Kossek/C. Zwiauer (Hrsg.), Universität in Zeiten von Bologna. Zur Theorie und Praxis von Lehr- und Lernkulturen (S. 111_119). Wien: V\&R unipress.

Reiber, K./Tremp, P. (2007). Eulen nach Athen! Forschendes Lernen als Bildungsprinzip. In B. Behrendt/H.-P. Voss/J. Wildt (Hrsg.), Neues Handbuch Hochschullehre. 30. Ergänzungslieferung. A 3.6 (S. 1-14). Berlin: Raabe. 
Rumpf, H. (2007). Anfängliche Aufmerksamkeiten und ihre Verdrängung - Über bleibende Probleme, Wissenschaft zu lehren. In K. Reiber/R. Richter (Hrsg.), Entwicklungslinien der Hochschuldidaktik - Ein Blick zurück nach vorn. Dokumentation der gleichnamigen Tagung vom 29.11. bis 1.12. 2006 in Tübingen (S. 43-55). Berlin: Logos.

Spoun, S. (2007). Universität hat Zukunft - Gestaltungsperspektiven am Beispiel der Universität Lüneburg. In A. Dudeck \& B. Jansen-Schulz (Hrsg.), Zukunft Bologna!?: Gender und Nachhaltigkeit als Leitideen für eine neue Hochschulkultur (S. 33-43). Frankfurt am Main: Lang Verlag.

Tremp, P./Futter, K. (2012). Forschungsorientierung in der Lehre: Curriculare Leitlinie und studentische Wahrnehmungen. In T. Brinker/P. Tremp (Hrsg.), Einführung in die Studiengangentwicklung (S. 69-79). Bielefeld: W. Bertelsmann Verlag.

Tremp, P./Hildbrand, T. (2012). Forschungsorientiertes Studium - universitäre Lehre: das »Züricher Framework« zur Verknüpfung von Lehre und Forschung. In T. Brinker/P. Tremp (Hrsg.), Einführung in die Studiengangentwicklung (S. 101-116). Bielefeld: W. Bertelsmann Verlag.

Webler, W.-D. (2007). Geben wir mit der Akkreditierung das Hochschulniveau unserer Studiengänge preis? Zur Differenz von Schule und Hochschule. Das Hochschulwesen, 55(1), 15-20.

Webler, W. D. (2008). Zur Entstehung der Humboldtschen Universitätskonzeption: Statik und Dynamik der Hochschulentwicklung in Deutschland-ein historisches Beispiel. Bielefeld: UVW.

Weyland, U. (2010). Zur Intentionalität Schulpraktischer Studien im Kontext universitärer Lehrausbildung. Paderborn: Eusl.

Wildt, J. (2003). »The Shift from Teaching to Learning « - Thesen zum Wandel der Lernkultur in modularisierten Studiengängen. In Fraktion Bündnis 90 / die Grünen Landtag NRW (Hrsg.), Unterwegs zu einem europäischen Bildungssystem. Reform von Studium und Lehre an den nordrhein-westfälischen Hochschulen im internationalen Kontext (S. 14-18). Düsseldorf.

Wildt, J. (2005). Auf dem Weg zu einer Didaktik der Lehrerbildung? Beiträge zur Lehrerbildung, 23(2), 183-190.

Wildt, J. (2009). Forschendes Lernen: Lernen im »Format« der Forschung. Journal Hochschuldidaktik, 20(2), 4-7.

Open Access This chapter is licensed under the terms of the Creative Commons AttributionNonCommercial-NoDerivatives 4.0 International License (http://creativecommons.org/licenses/bync-nd/4.0/), which permits any noncommercial use, sharing, distribution and reproduction in any medium or format, as long as you give appropriate credit to the original author(s) and the source, provide a link to the Creative Commons licence and indicate if you modified the licensed material. You do not have permission under this license to share adapted material derived from this chapter or parts of it.

The images or other third party material in this chapter are included in the chapter's Creative Commons licence, unless indicated otherwise in a credit line to the material. If material is not included in the chapter's Creative Commons licence and your intended use is not permitted by statutory regulation or exceeds the permitted use, you will need to obtain permission directly from the copyright holder.

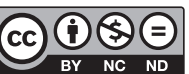

